\title{
Structural Change and Economic Development in China and India
}

\author{
Vittorio Valli and Donatella Saccone ${ }^{12}$
}

\begin{abstract}
The comparison of the periods of rapid economic growth in China since 1978 and India since 1992 markedly show different patterns of development and structural change. However, both countries experienced some advantages of "relative economic backwardness" and some aspects of the "fordist model of growth". China had an anticipated and deeper structural change, spurred mainly by economic reforms and the growth of the internal market in the 1980s, and, since the mid-1990s, by a very rapid penetration of its industrial products in the world market.

However, a substantial part of China's exports in medium and high tech sectors are due to joint-ventures with foreign multinationals. India had a more balanced structural change and a slower insertion in the world market, although some sectors, such as software, steel, automotive and pharmaceuticals are recently increasing their share in the world markets. Owing to the huge number of micro-enterprises and the great size of the informal sector, India benefited much less than China from the economies of scale and from the third wave of the "fordist model of growth". Both countries, but in particular China, experienced negative externalities of this recent phase of rapid growth, such as higher inequalities, pollution and urban congestion.
\end{abstract}

JEL-Classification: O11, O53, O57, P51.

Keywords: economic development, structural change, fordist model of growth, China's economy, India's economy.

\section{Introduction}

China since 1978 and India since 1992 have passed through a phase of very rapid economic growth accompanied by very important structural changes in the productive systems and severe and largely unresolved social problems. The objective of this paper is to evaluate and compare some aspects of the different growth patterns of the two

\footnotetext{
${ }^{1}$ Department of Economics, University of Turin

${ }^{2}$ Paragraphs 2, 3 and 4 are due to Vittorio Valli (vittorio.valli@unito.it); paragraphs 5, 6 and 7 are due to Donatella Saccone (donatella.saccone@unito.it). This paper belongs to a Vittorio Alfieri research project on the comparative analysis of India's and China's economies. We thank the CRT foundation for financial support. We thank also Giovanni Balcet, Silvana Dalmazzone, Mario Deaglio, Sean Dougherty, May Gicquel, Giovanni Graziani, Claudio Grua, Angus Maddison, Xavier Richet, Joel Ruet, Lino Sau, and all the participants to a workshop held in Turin on April 17-18, 2009 for their useful comments to the main theses of this paper.
} 
economies analyzing in particular the relations between structural change and economic development.

In doing so, we will utilise three concepts: Gerschenkron's "relative economic backwardness" (Gerschenkron, 1962; Fuà, 1980), "the fordist model of growth" (Valli, 2002, 2005, 2009) and Syrquin's distinction between the productivity effect and reallocation effect (Syrquin, 1986). The first concept is well known and stresses the fact that an emerging backward economy may benefit from some advantages, such as the adoption of modern technologies coming from more advanced countries and the possibility of transferring large masses of the labour force from low productivity sectors (agriculture and traditional tertiary activities) to sectors with higher productivity (industry and modern services).

The second concept, which is not to be confused with the more general concept of "Fordism" of Gramsci or of the French regulation school, ${ }^{3}$ is mainly associated to a phase of strong growth of some interlinked industrial and service sectors where scale economy and network economies are of crucial importance.

The third concept is a useful device to decompose productivity growth and comes from a long and important tradition of studies on structural change and development carried on by authors such as Kuznets (1966), Chenery and Syrquin (Chenery et al., 1979; Chenery, Robinson, Syrquin, 1986; Syrquin, 1986; IMF, 2006).

\section{The Third Wave of the Fordist Model of Growth}

The US experienced the first wave of the fordist model of growth for some decades following 1908. ${ }^{4}$ West Europe, Japan and the four Asian tigers passed through their second wave in the 1950s and the 1960s. Since the late sixties, the US, Western Europe and Japan experienced a crisis of the fordist model and have entered a postfordist phase. In contrast, China and India have entered the third wave of the fordist model of growth respectively in the 1980s and the 1990s, benefiting at the same time from some aspects of post-fordism and from several advantages of relative economic backwardness.

In the US the crucial sectors of the fordist model of growth were the automobile industry with all its interlinked sectors (steel, oil, tyres, auto repair, construction of roads and motorways, etc.). When in 1908 the Ford motor corporation launched, as a mass production product, the new Model T, which was much less expensive than pre-existing cars, it greatly accelerated the demand and the diffusion of the automobiles in the US market, and stimulated a rapid expansion of the steel, tyre and oil industries, road building, etc. In the 1980s in China, in a very different economic and socio-political context, the crucial sectors of the fordist model of growth were instead the electrical domestic appliances and their interlinked sectors (steel, plastics, electricity, etc.). In the

\footnotetext{
${ }^{3}$ While our concept of "fordist model of growth" mainly regards the core of economic transformations, the concept of Fordism of the French regulation school (Aglietta, Boyer and other authors) is much wider and regards also the relations of the economic aspects with socio-political and institutional changes, the organization of labour and of production in the firms and the social conditions of workers. Their approach, which is partly a derivation of Gramsci's concept of Fordism, is fascinating, but it is probably overly ambitious, since it implies the existence of a fully integrated social science.

${ }^{4}$ For a more complete analysis of the three waves of the fordist model of growth and the case of China see Valli (2009).
} 
1990s in China there was the addition of microelectronics, telecommunication and energy. Finally, since the 2000s, there also has been a rapid growth in the production of industrial vehicles, motorcycles and automobiles. In India, since 1992, machinery, household electric appliances, steel, pharmaceuticals, and, more recently, software services, telecommunication, motorcycles, automobiles and air communication have been the crucial dynamic sectors.

\section{Structural Transformation}

Most empirical analyses about structural transformation have two severe shortcomings. They often only consider the changes between the three great productive branches: agriculture, industry, services. However, also the changes among the different sectors of industry and services have great importance. Also the chance given to young school leavers not to remain unemployed or underemployed in agriculture and to find a job in industry or in services, which in general pay higher wages than agriculture, or to find a job in modern industrial or service sectors, which in general pay higher wages than the traditional ones, is usually overlooked or underestimated. Moreover, most empirical studies do not adequately consider the five main "virtuous circles" embedded in the "fordist model of growth".

The first virtuous circle can have a huge importance and consists in the fact that the rapid growth of production may generate economies of scale or network economies, higher productivity, higher profits, higher investment, further increase in productivity and production (see Figure 1). This feedback is associated with the rapid growth of industrial sectors where economies of scale are important, such as TV sets, refrigerators, washing machines, automobiles, steel, chemicals, PCs, mobile phones, etc. This effect is particularly strong in the period in which the internal demand for these goods rises very fast because several families buy their first TV set, or refrigerator, or their first PC, or mobile phone, etc. The effect becomes much weaker when economies of scale are fully exploited or when the sectors become mature, with substitution demand predominant.

The second important "virtuous circle" operates though aggregate demand. The rapid increase in productivity leads to a rapid increase in unit wages without reducing profit margins. This trend, if accompanied by a rise in employment, determines a fast increase in total wages and thus in consumption, which can favour, together with the increase in total profits, a substantial increase in investment. The rise in consumption and investment leads to a rapid increase in internal demand. 
Figure 1. The fordist model of growth in China

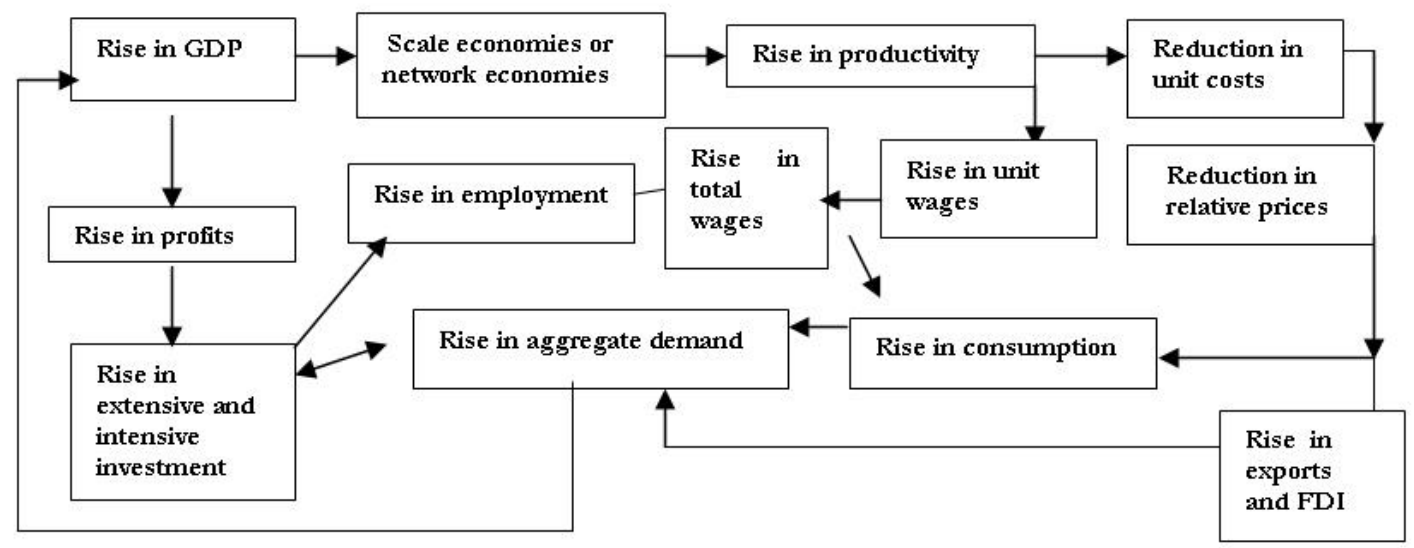

Source: the chart is derived from V alli (2002).

After some years, the improvement in productivity also leads to an increase in external competitiveness and exports and in the attractiveness of foreign direct investment. Internal demand-led growth can thus gradually become an export-led growth, as it has already happened in China, but not yet fully in India.

The third "virtuous circle" operates through total profits and investment. The rapid increase in labour productivity permits a substantial rise in total sales and then in total profits, provided that profit margins remain relatively stable. This leads to a rapid rise in both intensive and extensive investment. The former improves labour productivity, while the latter leads to an increase in employment and thus to a rise in total wages, consumption and aggregate demand, communication facilities, etc.

The fourth "virtuous circle" regards relative prices and the demand for selected goods and services. The very rapid increase in productivity in industrial sectors with economies of scale or network-economy service sectors can contribute to reduce the prices of their goods or services relative to the average level of prices. The fall in relative prices of these goods or services may boost their demand. The rapid increase in demand favours a rapid rise in profits and investment, contributing to the overall growth of the economy.

The fifth virtuous circle relies on the increase of taxation which accrues to the state and local authorities due to the rapid rise in production and in sales. It facilitates the financing of schools, research and development investment, transport and communication facilities, etc.

Naturally, the positive effects of these virtuous circles are accompanied by negative effects such as the greater division and fragmentation of labour and the increase in labour intensity and alienation in big factories. There is, moreover, a rapid increase in urban congestion and pollution, due to the rapid rise of the circulation of automobiles and other vehicles. Finally, there is a strong increase in energy consumption associated to the rapid economic growth and the greater diffusion of vehicles, PCs and domestic electrical appliances. 
Unfortunately, there is no comprehensive theory which can account for the virtuous circles, ${ }^{5}$ but the scheme depicted in Figure 1 may provide a general framework for the interpretation of some important aspects of the "fordist model of growth" as it operates in the two great emerging Asian economies.

\section{Growth and Structural Change in China and India since 1978}

In 1978 China and India were two developing countries, with a very low level of per capita GDP and very different political, social and economic institutions. Both countries could be considered "latecomer countries" in Gerschenkron's words, but, with a very low industrialization pace, they had not been able to exploit the advantages of relative economic backwardness in any meaningful way. The degree of poverty of a very large part of their population and the development model chosen by their governments had also prevented the two countries from starting any form of "fordist model of growth".

Figure 2: Per capita GDP in PPPs in China and India: 1978-2008 (international US \$ 1990)

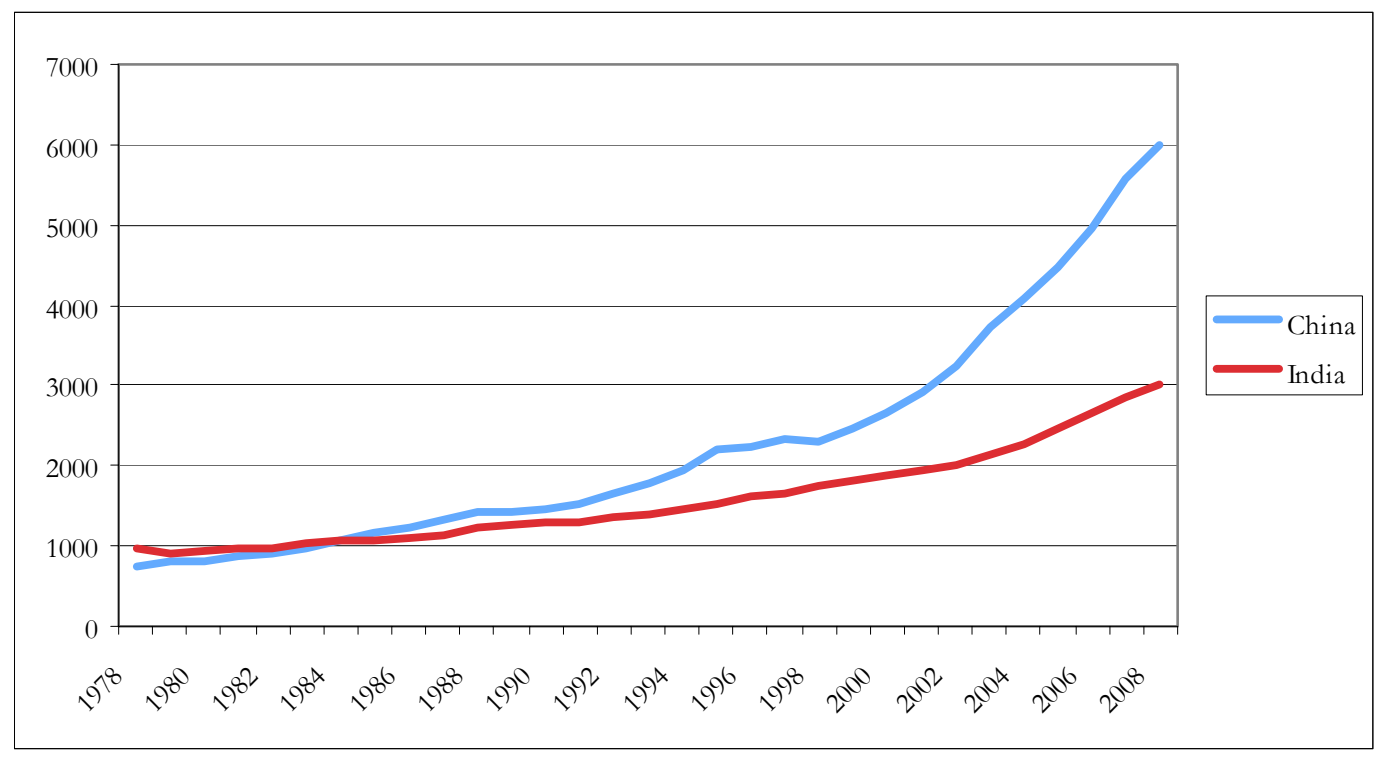

Source: GGDC (2009).

After the 1978 economic reforms China has experienced very rapid economic growth, and thus its economy could begin to exploit both the advantages of relative economic backwardness and some aspects of the "fordist model of growth". In terms of GGDC estimates of total per capita GDP in purchasing power parities, China had a partial, but impressive catching up towards the US, rising from $4.1 \%$ of the US per

\footnotetext{
${ }^{5}$ Pasinetti (1981) with his multisectoral growth model probably gives the most comprehensive theoretical approach which can explain both the changes in relative prices and part of the effects of technical progress on productivity growth and sectoral demand, while the neo-classical Solowian growth models and most endogenous growth models, being aggregate, do not explain the changes in relative prices. Neo-Kaldorian approaches stress the importance of economies of scale and the relation between product and productivity growth (Verdoorn's law), but overlook the important effects associated to the long-run changes in relative prices.
} 
capita GDP in 1978 to $19.1 \%$ in $2008,{ }^{6}$ while India passed from $5.3 \%$ in 1978 to $9.6 \%$ in 2008, accelerating its economic growth mainly since 1992 (see Figure 2).

In 1978 per capita GDP in PPPs was higher in India than in China, but China's overtook the Indian level in 1984 and the gap between the two countries widened in the succeeding years. As we will see in the next paragraph, the intensity of growth and structural change was larger in China than in India and the phase of rapid growth was anticipated in China by about fifteen years. India could thus in a more limited and delayed way than China exploit the advantages of "relative economic backwardness" and some of the features of the fordist model of growth. In India most enterprises are very small and the informal economy is huge and growing over time, so that the advantages of economies of scale have been much lower than in China.

In China the first wave of reforms mainly regarded agriculture, while in the 1980s and 1990s the second wave of reforms mainly involved industry, the services, property rights and institutions, and the third wave of reforms in the late 1990s and in the 2000s mainly regarded banking, finance and above all the rapid enlarging of international economic relations.

In 1978 China was a predominantly agrarian economy, with $70.5 \%$ of the labour force and $28.2 \%$ of GDP in agriculture, forestry and fishing. In 2007 the situation had completely changed as China experienced a rapid and widespread industrialisation and tertiarisation process. In 2007 the primary sector shares in employment and value added went down respectively to $40.8 \%$ and $11.3 \%$, while the secondary sector (industry and construction) increased to $26.8 \%$ and $48.6 \%$ and the tertiary sector went up to $32.4 \%$ and $40.1 \%$ (see Table 1). However, in 1978 in China the share of the tertiary sector, both in terms of employment and of value added, was very low if compared with market economies at the same level of development, due to the priority that planned socialist countries used to give to "productive" sectors, such as agriculture and industry, over "unproductive sectors", such as a large part of the tertiary sector. This attitude changed in the last decades as long as the space of the market economy and of private ownership was gradually allowed to increase.

Table 1. Employment and value added by sector in China ( $\%$ of total)

A) Percentages of total employment in China

\begin{tabular}{|l|l|l|l|l|l|}
\hline Sectors & $\mathbf{1 9 7 8}$ & $\mathbf{1 9 8 9}$ & $\mathbf{1 9 9 7}$ & $\mathbf{2 0 0 5}$ & $\mathbf{2 0 0 7}$ \\
\hline $\begin{array}{l}\text { Agriculture, forestry, animal } \\
\text { husbandry, fishing }\end{array}$ & 70.5 & 60.1 & 49.9 & 44.8 & 40.8 \\
$\begin{array}{l}\text { Industry, mining, quarrying, } \\
\text { construction }\end{array}$ & 17.3 & 21.6 & 23.7 & 23.8 & 26.8 \\
$\begin{array}{l}\text { Services } \\
\text { Total economy }\end{array}$ & 12.2 & 18.3 & 26.4 & 31.4 & 32.4 \\
\hline
\end{tabular}

Sources: NBS (2007), pp. 27, 34 for 1978-2005 and NBS (2008), p. 109 for 2007.

6 See GGDC (2009). The recently revised estimates of the World Bank for China and India are significantly lower, but the methodological bases of such large revisions in comparison with the previous World Bank data and alternative estimates are controversial. On this debate, see World Bank (2009) and Maddison, Wu (2008). 
B) GDP in the main branches of the Chinese economy: 1978- 2007 ( $\%$ of total GDP at current prices)

\begin{tabular}{|l|l|l|l|l|l|}
\hline Sectors & $\mathbf{1 9 7 8}$ & $\mathbf{1 9 8 9}$ & $\mathbf{1 9 9 7}$ & $\mathbf{2 0 0 5}$ & $\mathbf{2 0 0 7}$ \\
\hline $\begin{array}{l}\text { Agriculture, forestry, animal } \\
\text { husbandry, fishing }\end{array}$ & 28.2 & 25.1 & 18.3 & 12.2 & 11.3 \\
$\begin{array}{l}\text { Industry, mining, quarrying, } \\
\text { construction }\end{array}$ & $\mathbf{4 7 . 9 .}$ & 42.8 & 47.5 & 47.7 & 48.6 \\
$\begin{array}{l}\text { Services } \\
\text { Total economy }\end{array}$ & $\begin{array}{l}23.9 \\
100.0\end{array}$ & $\begin{array}{l}32.1 \\
100.0\end{array}$ & $\begin{array}{l}34.2 \\
\text { Source: NBS (2008), p.38. }\end{array}$ & 40.1 & 40.1 \\
\hline
\end{tabular}

However, China's structural transformation and China's fordist wave passed through two different phases. Between 1978 and the mid 1990s the rapid growth was mainly based on rapid accumulation and on the growth of the internal market, while since the late 1990s and especially after the entrance in WTO, from 2001 up to the 2008-2009 global crisis, they were violently spurred by the rapid rise of exports and the great inflow of foreign direct investment. In the last six years the acceleration of exports brought about a recovery of the employment share of industry and a slowing down in the rise of the share of the tertiary sector. This was partly due to the rate of growth of some traditional industrial sectors such as textiles, cloth and leather articles, which could find a growing and easier access into the world markets; and partly to an entrance in new sectors such as ICT and later in automobiles, facilitated by several large jointventures with foreign enterprises. A substantial part of the increase of exports in middle and high technical products was made by joint-ventures and foreign companies operating in China (OECD, 2005). However, in the last four to five years there were also growing outward FDI with a number of acquisitions of foreign firms and foreign natural resources by Chinese corporations.

Since 1978 in India the industrialisation process was less rapid and widespread than in China, but the services sector, which in 1978 was already relatively larger than in China, increased relatively faster than in China in terms of value added, but not as regards employment, as we will see in the next paragraphs.

It must be stressed that in both countries the labour productivity of industry (including construction) and of services was much higher than the labour productivity of agriculture. ${ }^{7}$ Therefore the transfer of many employees from agriculture to industry and services has contributed to the pace of economic growth. ${ }^{8}$ The possibility of young school leavers to enter industry or services rather than remaining unemployed or underemployed in agriculture, thus gaining much higher incomes or wages, was even more important.

However, in India most people moving from rural to urban areas could only find jobs in industry or service activities of the "informal sector", earning much less than people working in the formal sector of the economy.

The Chinese government instead tried to hinder the possibility of moving from rural villages to urban centres by means of legal and administrative restrictions.

\footnotetext{
7 See paragraphs 5-6 and, for China, Maddison (2007), p. 70.

8 According to Maddison (2007, p. 70) in the 1978-2003 period the impact of redistribution of employed labour force among the three great branches could be estimated to $2.01 \%$ points of average annual rate of growth of real GDP, equal to $25.6 \%$ of the overall rate of growth (+7.85\%). See also IMF (2006), Herd and Dougherty (2007) and Bossworth, Collins (2008), for other estimates.
} 
However, many workers left the rural areas creating a great reserve of precarious jobs in the cities, although the government tried to improve the conditions of life in rural areas encouraging the expansion of industrial and services activities through locally controlled public firms (TVEs), private firms and joint ventures with foreign multinationals, all strongly contributing to industrialisation and to rapid economic growth.

After the post-1978 reforms in China, the initial source of capital formation for the rapid growth of TVEs was mainly due to the fast rise of productivity and surplus in agriculture, followed then by substantial investment in industry and services, spurred by the fact the government's policy of maintaining very favourable prices for industrial and tertiary products compared with agriculture goods. The richest rural zones thus had growing profits, which partly served to finance the use of fertilizers and machines in agriculture, and thus to increase agricultural productivity, and partly were devoted to the creation or expansion of TVEs, private firms and joint ventures with foreign firms both in industry and in the services. Moreover the rise in agricultural and industrial activities led to a further growth of the demand for modern and traditional services, for residential and non-residential construction and for infrastructure (roads, bridges, electricity, railways, telecommunication, ports, airports, etc.). On the opposite end, the poorest agricultural zones experienced a very low growth in industry, services and public infrastructure, so that regional inequalities tended to rapidly widen.

The expansion of TVEs, private firms and joint ventures with foreign multinationals, made up for the decline of large state firms and led to a rapid increase in employment in industry and services, which contributed to almost $80 \%$ of the increase in total employment in the 1978-1995 period and to a substantial share of the increase in the 1995-2008 period.

However, in the last three decades, in addition to the great transformation between the three main branches - agriculture, industry and services - there was also a dramatic structural transformation within industry and within the tertiary activities. Table 2 gives an idea of the very rapid growth in the volume of physical output in some modern industrial and service sectors and of the consistent, but on average lower, rate of growth of traditional sectors, such as the production of yarn, cloth and refined sugar.

In 1980 the main industrial sectors were the traditional ones: textiles, clothes, food and beverage, bicycles, etc., with a limited presence of some scale intensive sectors such as steel, chemicals and fertilizers. Electricity and telecommunication services were uncommon and unreliable and residential constructions were curtailed, with very small and crowded apartments in the cities.

In 1995 and much more by 2007 the situation had radically changed (Maddison, 2007). While in 1978 textiles in China had been by far the most important sector in terms of the percentage of total value added, since the mid-1990s the electrical and nonelectrical machines and chemicals surpassed textiles. Also the growth in production quantities of the goods produced by modern industrial products such as PCs and mobile phones was much faster than for textiles and most other traditional sectors.

Residential and non-residential construction was booming, especially in big urban centres. Richer provinces built a relatively good network of public and private infrastructures, but pollution, congestion and energy dependence from abroad were also rapidly rising. 
Since 1992 China has become a net importer of oil and other energy sources and its imports have grown rapidly over time. Moreover, China continues to heavily rely on its abundant coal reserves, thus increasing air pollution.

Table 2. Growth of some industrial and service sectors in China: 1980-2007

a) Physical quantities (output)

\begin{tabular}{|l|l|l|l|l|}
\hline Sectors & $\mathbf{1 9 8 0}$ & $\mathbf{1 9 9 0}$ & $\mathbf{2 0 0 4}$ & $\mathbf{2 0 0 7}$ \\
\hline Refrigerators, millions & 0.05 & 4.60 & 30.30 & 43.97 \\
TV sets, millions & 2.50 & 26.80 & 73.30 & 84.33 \\
\hline Crude steel, mlns. tons & 37.00 & 66.00 & 272.00 & 489.66 \\
\hline Chemical fibres, million tons. & 0.45 & 1.65 & 14.20 & 23.90 \\
\hline PCs, millions & - & - & 45.1 & 120.73 \\
Mobile phones, millions & - & - & 233.0 & 548.58 \\
\hline Motor vehicles, millions & 0.22 & 0.50 & 5.10 & 8.88 \\
\hline of which automobiles & 0.10 & 0.30 & 2.3 & 4.80 \\
\hline Electricity, billion Kwh & 300.60 & 621.20 & 2187.0 & 3277.72 \\
Telephones, millions & 2.14 & 6.84 & 312.6 & - \\
\hline Refined sugar, million tons & 2.57 & 5.82 & 10.34 & 12.71 \\
Yarn, million tons & 2.93 & 4.63 & 12.91 & 20.68 \\
\hline Cloth, 100 million m & 134.70 & 188.80 & 482.10 & 675.26 \\
\hline
\end{tabular}

B) Indexes $(1980=100)$

\begin{tabular}{|c|c|c|c|c|}
\hline Sectors & 1980 & 1990 & 2004 & 2007 \\
\hline Refrigerators, millions & 100.0 & 920.0 & 6060.0 & 8794.0 \\
\hline TV sets, millions & 100.0 & 1072.0 & 2932.0 & 3373.2 \\
\hline Steel, million tons & 100.0 & 178.4 & 735.1 & 1323,4 \\
\hline Chemical fibres million tns. & 100.0 & 366.7 & 3155.6 & 5311.1 \\
\hline Motor vehicles, millions & 100.0 & 227.3 & 2318.2 & 4036.4 \\
\hline of which automobiles & 100.0 & 300.0 & 2300.0 & 4800.0 \\
\hline Electricity, billion Kw. & 100.0 & 206.7 & 727.5 & 1090.4 \\
\hline Telephones, millions & 100.0 & 319.6 & 14609.3 & - \\
\hline Refined sugar, million tons & 100.0 & 226.5 & 402.2 & 494.7 \\
\hline Yarn, million tons & 100.0 & 158.1 & 441.3 & 706.8 \\
\hline Cloth, 100 million $\mathrm{m}$ & 100.0 & 140.2 & 357.9 & 501.3 \\
\hline
\end{tabular}

See Valli (2009), p.16. Sources: China National Burean of Statistics, China Statistical Yearbooks (various years). 
The rapid growth in household electrical appliances, telecommunication, and then PC, steel, means of transportation and finance led to the rise and consolidation of a middle and upper middle class, concentrated mainly in the great urban coastal zones.

Thus social and economic inequalities strongly increased. In particular there was a marked increase in overall inequality indexes, such as the Gini index, which surpassed the levels of the US and of most industrialized countries, and a strong rise in regional inequalities among provinces.'

India had a marked acceleration of economic growth after the debt crisis of 1991 and the ensuing economic reforms of Prime Minister Narasimha Rao of the Indian Congress Party. ${ }^{10}$ According to several authors, the essential reforms that led to the period of rapid growth were gradually introduced starting in the mid-1980s, while after 1992 there was a sharp rise in the rate of economic growth. In the 1992-2008 period, the rate of growth of real GDP and real GDP in PPA markedly increased surpassing respectively $7 \%$ and $5 \%$.

The phase of rapid growth in the Indian economy led, with less intensity and a delay of 14-15 years if compared with China, to a gradual decrease of the agricultural share in employment and value-added, and an increase in the share of industry and services (see Table 3).

Table 3. Employment and value added by sector in India (\% of total)

\begin{tabular}{|l|l|l|l|}
\hline EMPLOYMENT & $\mathbf{1 9 7 8}$ & $\mathbf{1 9 9 3}$ & $\mathbf{2 0 0 4}$ \\
\hline Agriculture, forestry and fishing & 71 & 64 & 57 \\
\hline Industry & 13 & 15 & 18 \\
\hline Services & 16 & 21 & 25 \\
\hline Total & 100 & 100 & 100 \\
\hline VALUE ADDED & & & \\
\hline Agriculture, forestry and fishing & 44 & 33 & 22 \\
\hline $\begin{array}{l}\text { Industry and construction } \\
\text { Services }\end{array}$ & 24 & 28 & 28 \\
\hline $\begin{array}{l}\text { Total } \\
\text { See Bossworth, Collins (2008), p. 49. Sources: India National Accounts, Indian National Sample Survey Organization. }\end{array}$ & 32 & 39 & 50 \\
\hline
\end{tabular}

\footnotetext{
9 See, for example, Galbraith, Kritynskaia, Wang (2004), Saccone (2008).

10 According to F.R. Frankel (2005), p. 591, "the government drastically cut back the number of industries reserved for the public sector, removed compulsory licensing on the private sector for starting [a business] and expanding new enterprises in virtually all industries; devalued the rupee; introduced current account convertibility to pay balances on the current export and import (trade) account; removed quantitative quotas on imports; steadily reduced tariff levels on import; lifted restrictions on majority foreign investment in a wide range of industries; allowed foreign companies to borrow funds in India, raise public deposits and expand their operations by creating new businesses, and permitted foreign financial institutions to make direct portfolio investment in India's two stock markets".
} 
In India the 1992-2008 period of rapid growth was accompanied by some aspects of the "fordist model of growth", although much less importantly than in China.

While in China this model of growth began in the 1980s and was essentially based upon a large and gradually increasing number of industrial sectors, in India it was delayed by over a decade. Moreover, it was less based on industry, but more on services, such as banking, transport and telecommunication and above all on the production and export of a variety of software services. However, if we take into consideration the fact that India reached the Chinese 1995 per capita level of GDP in PPPs about 12 years later than China and began its period of rapid growth about 14 years later, it is not completely true that while China is becoming the "factory of the world", India is becoming the "office of the world". In India several industrial sectors such as machinery, chemicals, steel, pharmaceutics, three-wheel vehicles, motorcycles and, more recently, microelectronics hardware and automobiles, had a relevant and accelerated growth, although often inferior and delayed of some years with respect to the one registered in China. As we can see in Table 4, although in the period 1993-94/2006-7 a traditional sector (beverages, tobacco and related products) had the highest rate of growth in manufacturing industries, modern economy-of-scale sectors such as transport equipment and parts, machinery, non-metallic mineral products, chemicals, had strong and above-average dynamics.

We take three examples: the steel, automobile and automotive components sectors in India. The giant Indian steel corporation Mittal has rapidly grown and has recently acquired the control of two of the leading European steel corporations. Moreover, the larger automotive sector in India has risen from 3.5 million vehicles in 1995-6 (of which 2.2 million scooters and motorcycles, about 350000 cars and 129000 buses and trucks) to 9.7 million vehicles in 2005-6 (of which 7.2 million scooters and motorcycles, about 1.1 millions cars and 219000 buses and trucks) (Richet and Ruet, 2008).

After 1999, China's production of passenger cars surpassed India's production. However, although the major Indian car maker remains Maruti, which is controlled by a Japanese corporation (Suzuki), from the technological point of view there is probably no Chinese national car producer (distinguished from joint ventures with Japanese or Western firms) as strong as India's Tata. This big corporation is developing its Nano project for small low-cost cars, has acquired Jaguar for luxury cars, has signed joint ventures with Fiat in India and in Latin America and all this will probably lead, after the world crisis, to a very fast growth in output both inland and abroad (Balcet and Bruschieri, 2008).

Finally, the Indian corporation Bharat Forge, which makes components for cars and trucks, has rapidly grown in recent years and has invested massively abroad, also acquiring the control of a leading German firm (Balcet and Bruschieri, 2008). 
Table 4. Output index for the manufacturing industry in India (base 1993-4 = 100; weights $*$ industry $=100$ )

\begin{tabular}{|c|c|c|c|c|c|c|}
\hline & Industry group & Weight & 1999-00 & 2004-05 & $2005-06$ & 2006-07 P \\
\hline 1 & $\begin{array}{l}\text { Beverages, tobacco and related } \\
\text { products }\end{array}$ & 2.38 & 192.1 & 345.9 & 400.3 & 444.5 \\
\hline 2 & Transport equipment and parts & 3.98 & 194.1 & 283.7 & 319.7 & 367.7 \\
\hline 3 & $\begin{array}{l}\text { Machinery and equipment } \\
\text { other than transport equipment }\end{array}$ & 9.57 & 182.5 & 279.4 & 312.8 & 357.1 \\
\hline 4 & Non-metallic mineral products & 4.4 & 220.8 & 244.3 & 271.1 & 305.8 \\
\hline 5 & Other manufacturing industries & 2.56 & 142.5 & 221.2 & 276.9 & 298.4 \\
\hline 6 & $\begin{array}{l}\text { Textile products (including } \\
\text { wearing apparel) }\end{array}$ & 2.54 & 156.1 & 219.6 & 255.5 & 285.0 \\
\hline 7 & $\begin{array}{l}\text { Basic chemicals and chemical } \\
\text { products (except products of } \\
\text { petroleum \& coal) }\end{array}$ & 14.0 & 164.6 & 238.6 & 258.5 & 283.4 \\
\hline 8 & Basic metal and alloy industries & 7.45 & 146.9 & 196.1 & 227 & 278.9 \\
\hline 9 & $\begin{array}{l}\text { Wool, silk and man- made fibre } \\
\text { textiles }\end{array}$ & 2.26 & 197.8 & 249 & 248.9 & 268.4 \\
\hline 10 & $\begin{array}{l}\text { Paper and paper products and } \\
\text { printing, publishing and allied } \\
\text { industries }\end{array}$ & 2.65 & 180.5 & 230.7 & 228.6 & 248.6 \\
\hline 11 & $\begin{array}{l}\text { Rubber, plastic petroleum and } \\
\text { coal products }\end{array}$ & 5.73 & 137.2 & 192.2 & 200.5 & 226.3 \\
\hline 12 & Food products & 9.08 & 140.3 & 167.3 & 170.6 & 185.2 \\
\hline 13 & $\begin{array}{l}\text { Metal products and parts } \\
\text { (except machinery and } \\
\text { equipment) }\end{array}$ & 2.81 & 137.8 & 166.3 & 164.4 & 183.2 \\
\hline 14 & Cotton textiles & 5.52 & 123.7 & 126.3 & 137 & 157.3 \\
\hline 15 & $\begin{array}{l}\text { Leather and leather\& fur } \\
\text { products }\end{array}$ & 1.14 & 135.5 & 156.9 & 149.3 & 150.2 \\
\hline 16 & $\begin{array}{l}\text { Wood and wood products; } \\
\text { furniture\& fixtures }\end{array}$ & 2.7 & 101.4 & 74.8 & 70.5 & 91 \\
\hline 17 & $\begin{array}{l}\text { Jute and other vegetable fibre } \\
\text { textiles (except cotton) }\end{array}$ & 0.59 & 105 & 107.2 & 107.7 & 90.7 \\
\hline & Manufacturing (Total) & 79.36 & 159.4 & 214.6 & 234.2 & 263.5 \\
\hline
\end{tabular}

Although in India a large mass of the population remains very poor, and therefore unable to buy almost any durable consumption goods, the rapid growth in the last 15 years made it possible for an increasing proportion of medium and high income people, mainly concentrated in urban areas, to have access to durable consumer goods, such as TV sets and other electric household appliances, scooters or three-wheel vehicles, and in the more affluent families, a PC and an automobile. From 1988-89 to 1998-9 the "higher income groups" (middle and upper middle class households, with an annual income over 75000 Rupees in 1998-9 prices) almost doubled in percentage of total 
households passing from $14 \%$ to $26 \%$ (Frankel, 2005, p. 596). ${ }^{11}$ However in 1998-99, their share rose to $47 \%$ of urban households, but only to $17 \%$ of rural households. Of these "higher income groups", about 150 million people lived in households with some purchasing power for durable consumer goods.

In any case, even if the availability of these goods was limited to a minority, although gradually rising, share of the population, India had become the fifth or sixth world market for a substantial number of durable consumer goods and of services. The latter are partly imported, but mainly they are produced domestically with relative prices steadily declining thanks to economies of scale and/or network economies.

\section{Factors Behind Productivity Growth: Sectoral Gains or Employment}

\section{Reallocation?}

Both China and India have witnessed impressive rises in labour productivity. It is then worth understanding the factors behind the productivity growth. By using the methodology proposed by Syrquin (1986), we decompose the productivity growth of China and India into two parts, intrasectoral productivity gains and intersectoral employment-shift. The first one is the so called 'productivity effect', due to changes of productivity within each sector; the second one relies on the 'reallocation effect', depending on the movement of workers across sectors which differ in terms of productivity. At first we carry out this exercise for the main economic sectors and subsectors, with particular attention to services. Finally, since manufacturing growth was relevant in both countries, we focus on structural changes within this subsector.

The methodology is based on a simple identity:

$$
\xi_{L}=\sum_{i}\left\lfloor\vartheta_{0}^{i}\left(\hat{X}^{i}-\hat{L}^{i}\right)+\left(\vartheta_{0}^{i}-\varepsilon_{0}^{i}\right) \hat{L}_{i}\right\rfloor
$$

Where $\xi_{L}$ represents the economy-wide productivity growth; $\vartheta_{0}^{i}$ and $\varepsilon_{0}^{i}$ the output share and the employment share of the sector $i$, respectively; $\hat{X}_{i}$ and $\hat{L}_{i}$ the output and the employment growth in the sector $i$. The first addend characterizes the component of economy-wide productivity growth which depends on the 'productivity effect', the second one the component related to the 'reallocation effect'. A productivity effect with negative sign reveals that the employment growth rate is higher than the output one. Analogously, a reallocation effect lower than 0 can be caused by two factors: the employment growth rate is negative or the employment share is higher than the output share. In general, sectors presenting $\vartheta_{0}^{i}$ greater than $\varepsilon_{0}^{i}$ are the most dynamic; the opposite is true for sectors with $\vartheta_{0}^{i}$ lower than $\varepsilon_{0}^{i}$.

11 The source of data is NCAER, Indian Market Demographics Report (2002). 


\section{China}

The National Bureau of Statistics of China provides yearly data on GDP at constant prices and employment by sector and subsector; they are published on the China Statistical Yearbooks. GDP data were revised in accordance to the results of the first China Economic Census 2004. The composition of GDP is reported for the following subsectors: agriculture, forestry, animal husbandry and fishery and services in support of these activities; industry (mining and quarrying, manufacturing, production and supply of electricity, water and gas); construction; transport, storage and post; wholesale and retail trades; hotels and catering services; financial intermediation; real estate; other services. Unfortunately, the subsector classification for employment data differs from the classification used for the GDP composition.

Table 5. Employed persons by sector and share in China, $1980=100$

\begin{tabular}{|l|l|l|l|l|l|l|l|}
\hline & $\begin{array}{l}\text { Total employed } \\
\text { persons }\end{array}$ & Primary & share & Secondary & share & Tertiary & share \\
\hline 1980 & 100.0 & 100.0 & 0.69 & 100.0 & 0.18 & 100.0 & 0.13 \\
1985 & 117.7 & 106.9 & 0.62 & 134.7 & 0.21 & 151.1 & 0.17 \\
1990 & 152.9 & 133.6 & 0.60 & 179.8 & 0.21 & 216.5 & 0.19 \\
1995 & 160.7 & 122.0 & 0.52 & 203.1 & 0.23 & 305.1 & 0.25 \\
2000 & 170.2 & 123.8 & 0.50 & 210.4 & 0.22 & 358.3 & 0.27 \\
2005 & 179.0 & 116.6 & 0.45 & 234.6 & 0.24 & 429.7 & 0.31 \\
2007 & 181.7 & 108.0 & 0.41 & 267.7 & 0.27 & 450.4 & 0.32 \\
\multicolumn{7}{|c|}{ Source: our calculations based on China Statistical Yearbook data (various years). } \\
\end{tabular}

Table 6. Employed persons (E) and productivity (P) by subsector in China, 1980=100

\begin{tabular}{|c|c|c|c|c|c|c|c|c|}
\hline & \multicolumn{2}{|c|}{$\begin{array}{l}\text { Agriculture, } \\
\text { forestry, animal } \\
\text { husbandry and } \\
\text { fishery }\end{array}$} & \multicolumn{2}{|c|}{$\begin{array}{l}\text { Industry } \\
\text { (manufacturing, } \\
\text { mining and utilities) }\end{array}$} & \multicolumn{2}{|c|}{ Construction } & \multicolumn{2}{|c|}{$\begin{array}{l}\text { Wholesale, retail } \\
\text { trade, hotels and } \\
\text { catering services }\end{array}$} \\
\hline & $\mathrm{E}$ & $\mathrm{P}$ & $\mathrm{E}$ & $\mathrm{P}$ & $\mathrm{E}$ & $\mathrm{P}$ & $\mathrm{E}$ & $\mathrm{P}$ \\
\hline 1980 & 100 & 100 & 100 & 100 & 100 & 100 & 100 & 100 \\
\hline 1985 & 107 & 139 & 124 & 129 & 205 & 83 & 160 & 156 \\
\hline 1995 & 113 & 197 & 164 & 343 & 335 & 138 & 562 & 93 \\
\hline 2000 & 115 & 231 & 133 & 687 & 358 & 173 & 914 & 86 \\
\hline \multirow[t]{3}{*}{2002} & 112 & 251 & 136 & 801 & 392 & 183 & 1092 & 86 \\
\hline & \multicolumn{2}{|c|}{ Finance } & \multicolumn{2}{|c|}{ Real estate } & \multicolumn{2}{|c|}{ Other services } & \multicolumn{2}{|c|}{ TOTAL ECONOMY } \\
\hline & $\mathrm{E}$ & $\mathrm{P}$ & $\mathrm{E}$ & $\mathrm{P}$ & $\mathrm{E}$ & $\mathrm{P}$ & $E$ & $\mathrm{P}$ \\
\hline 1980 & 100 & 100 & 100 & 100 & 100 & 100 & 100 & 100 \\
\hline 1985 & 169 & 173 & 250 & 71 & 174 & 99 & 124 & 133 \\
\hline 1995 & 462 & 229 & 523 & 161 & 367 & 120 & 185 & 244 \\
\hline 2000 & 618 & 234 & 786 & 141 & 500 & 153 & 218 & 318 \\
\hline 2002 & 718 & 229 & 938 & 145 & 566 & 168 & 236 & 348 \\
\hline
\end{tabular}


However, by merging the two sources of data, we obtain historical series for the following seven subsectors: agriculture, forestry, animal husbandry and fishery; industry (manufacturing, mining and utilities); construction; wholesale, retail trade, hotels and catering services; financial intermediation; real estate; other services (including community, social and personal services, transport, storage, post, telecommunication and others).

Figure 3. Number of employed persons by sector and subsector in China (10 000 persons)

By sector



By subsector

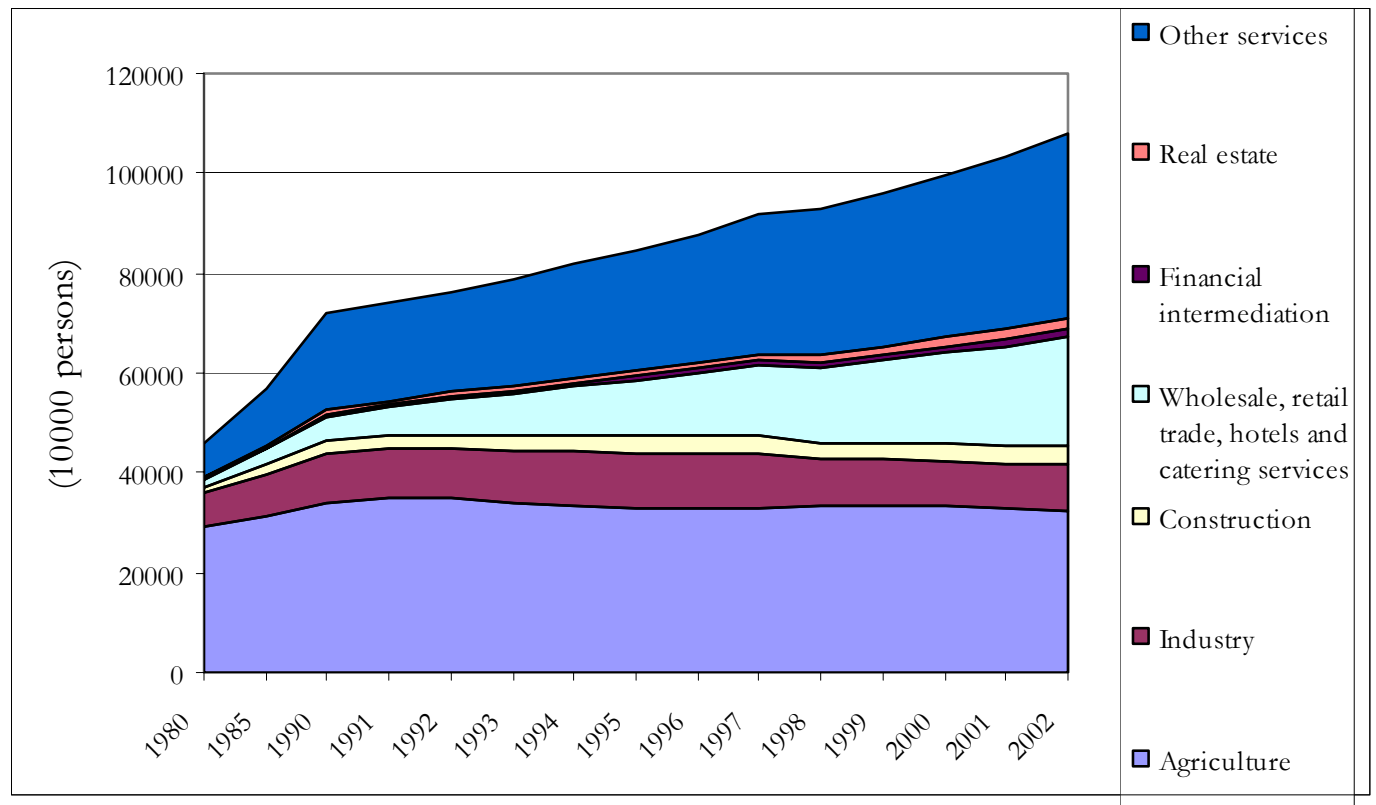

Source: China Statistical Yearbook (various years). "Agriculture" includes agriculture, forestry, animal busbandry and fishery; "Industry" refers to manufacturing, mining and utilities. 
Figure 4. Productivity level by sector and subsector in China - output per worker (yuan) - 1980 constant prices
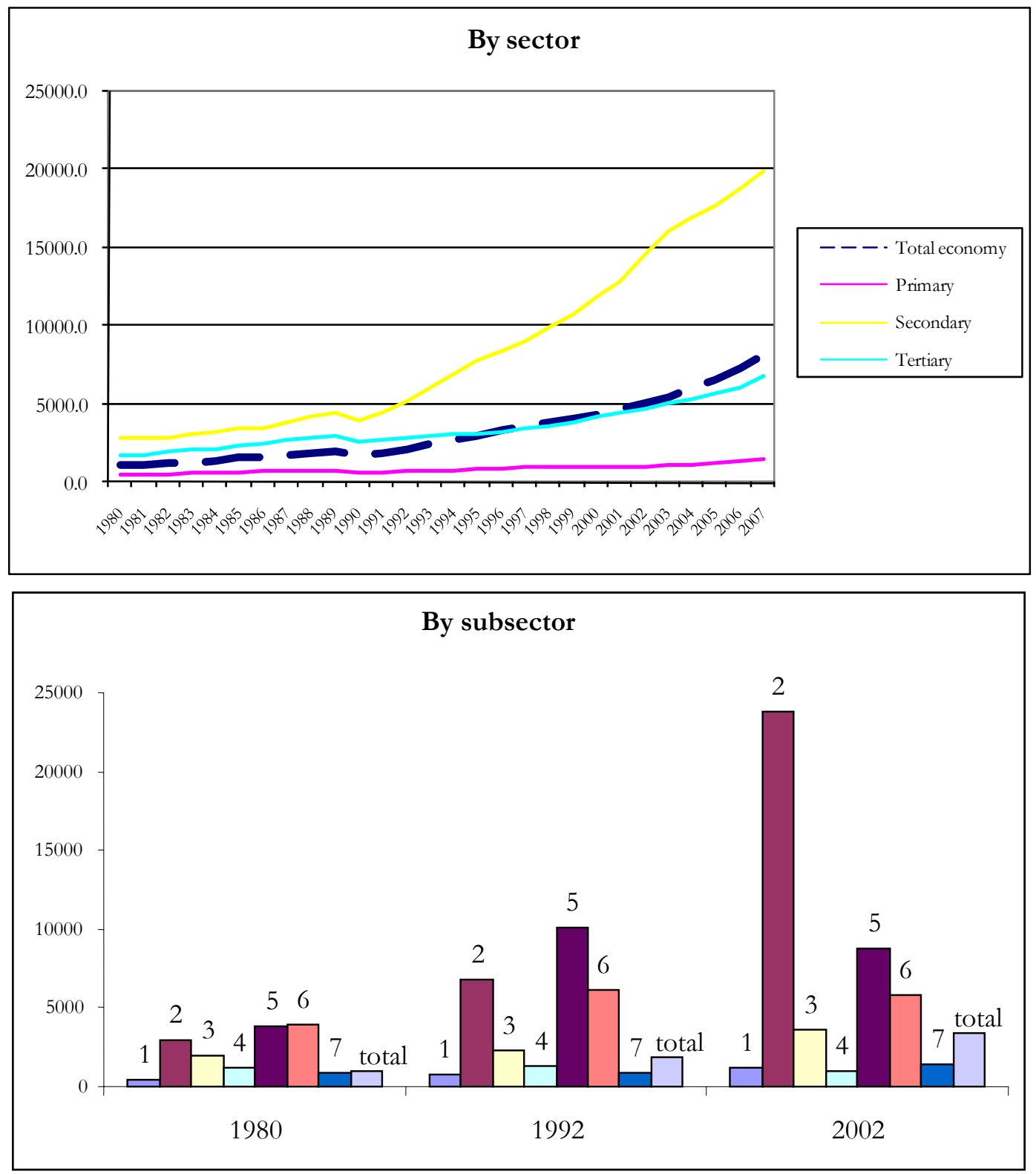

Source: our calculations based on CSY data (various years). Sectors are encoded in the following way: 1_ Agriculture, forestry, animal husbandry and fishery; 2_ Industry (manufacturing, mining and utilities); 3_ Construction; 4_Wholesale, retail trade, hotels and catering services; 5_ Financial intermediation; 6_ Real estate; 7_ Other services.

Over the period 1980-2007, total employment grew by 81.7\%. Although in 2007 the number and the share of employed persons in the primary sector were still higher with respect to the other two sectors, the situation dramatically changed if compared to 1980. In the first period, 1980-1992, the number of workers increased in all sectors (Figure 3).

However, from 1992 to 2007 the number of agricultural workers fell and it was counterbalanced by a rise in employment both in the secondary and tertiary sectors; looking at the growth rates, this rise was equal to 167.7 and 350.4 percent, respectively 
(see Table 5). In particular, from 1995 the tertiary sector exceeded the secondary sector with respect to the absolute and relative level of employment. In other words, at the end of the period considered, China had characteristics similar to both a developed and a developing country: the largest part of labour force was employed in agricultural activities (over $41 \%$ ), but the share of people working in services $(32 \%)$ was greater than the share engaged in mining, manufacturing, construction and utilities (27\%). In sum, an important reallocation of workers from the primary to the secondary and, above all, tertiary sectors occurred over the three decades.

This reallocation can be better understood by observing the second panel of Figure 3, in which absolute and relative employment are depicted at the subsector level. Focusing on the tertiary sector, we can see that some subsectors particularly benefited from the movement of workers from agriculture: on the one hand wholesale, retail trade, hotels and catering services, where the number of employees increased ten-fold in the period 1980-2002; on the other hand, other services (including community, social and personal services, transport, storage, post, telecommunication and others), where employment increased by a factor of five. Although employment also grew in real estate and financial intermediation services, the share of workers in these subsectors remained low (Table 6).

If we look at the productivity gains, data show that until the beginning of the 1990s they were modest in the whole economy and in each sector. However, starting from 1991, they began to increase; this increase was particularly evident in the secondary sector. In 2007, its productivity reached a level which was about 13 and 9 times that of the primary and the tertiary sectors, respectively (Figure 4). Focusing on the sub-sectoral level, we can not only see that four subsectors out of seven presented a relatively low level of productivity, but also that their productivity gains were modest: these subsectors are construction; wholesale, retail trade, hotels and catering services; other services (including community, social and personal services, transport, storage, post, telecommunication and others) and, as expected, agriculture. In 1980, just three subsectors were characterized by a relatively high level of productivity: financial intermediation and real estate, followed by industry. Even if productivity increased in all three subsectors, it is evident that in 2002 industrial productivity substantially exceeded all the others subsectors. The index of industrial productivity moved from 100 to 801 in the period 1980-2002 (Table 6).

It is worth remarking that employment growth was very low in industry, while it was substantial in subsectors 4 (wholesale, retail trade, hotels and catering services) and 7 (other services). It seems that the movement of workers didn't follow productivity gains or, better, that in some subsectors the employment growth was faster than the output growth. Conversely, in manufacturing, mining and utilities employment didn't notably grow, while output and, then, output per worker showed a dramatic rise.

The asymmetry between productivity increases and employment reallocation among sectors and subsectors is confirmed when we look at the decomposition of labour productivity growth (Table 7; for details, see Table A1, Statistical Appendix). It is evident that the economy-wide productivity gains were mainly due to the productivity increase within-sectors rather than to the movement of workers from low to high productivity sectors. This is particularly true in the period 1992-02, i.e. when productivity gains in industry became remarkable. In this period, indeed, they positively contributed to the economic growth (+108 percent), while the reallocation of workers counterbalanced this effect (-8 percent). In particular, the rise of productivity in industry 
drove economic growth by contributing $90 \%$ of gains; on the contrary, the movement of workers from agriculture to sectors in which employment grew faster than output reduced the overall labour productivity growth; the whole contribution of the tertiary sector was just of 0.2 percent. We also decompose the growth of productivity within industry, which includes manufacturing, mining and utilities. In this case, the importance of the productivity effect is even stronger. ${ }^{12}$

Table 7: Decomposition of labour productivity growth in China- percentage contribution by 7 subsectors and industry

\begin{tabular}{l|l|l|l|}
\cline { 2 - 4 } \multicolumn{1}{c|}{} & $\mathbf{1 9 8 0 - 9 2}$ & $\mathbf{1 9 9 2 - 0 2}$ & $\mathbf{1 9 8 0 - 0 2}$ \\
\hline 7 SUBSECTORS & & & \\
\hline PRODUCTIVITY EFFECT & 87.3 & 107.8 & 94.0 \\
REALLOCATION EFFECT & 12.7 & -7.8 & 6.0 \\
\hline TOTAL EFFECT & 100 & 100 & 100 \\
\hline INDUSTRY & & & \\
\hline PRODUCTIVITY EFFECT & 87.3 & 98.6 & 98.3 \\
REALLOCATION EFFECT & 12.7 & 1.4 & 1.7 \\
\hline TOTAL EFFECT & 100.0 & 100.0 & 100.0 \\
$\begin{array}{l}\text { Calculations are based on 1980 constant prices. Industry included manufacturing, mining and utilities. } \\
\text { Source: our calculations based on Cbina Statistical Yearbook data (various years) and Szirmai et al. (2005). }\end{array}$
\end{tabular}

\section{India}

In order to investigate factors behind the Indian productivity growth, we use the data provided by the Gröningen Growth and Development Centre (GGDC). The GGDC data refer to nine different subsectors: agriculture, forestry, and fishing; mining and quarrying; manufacturing; public utilities; construction; wholesale and retail trade, hotels and restaurants; transport, storage and communication; finance, insurance and real estate; community, social, personal and government services. Also in India total employment grew from 1980 to 2004 (see Figure 5 and Table 8). However, in India not only the share of people employed in the primary sector remained high $(62 \%)$, but the absolute number of agricultural workers increased $(+39 \%)$. Although the rise of employment was higher in the secondary and tertiary sectors $(131 \%$ and $114 \%$, respectively), in 2004 the number of persons working in agricultural activities was about 4 and 3 times the quantity of workers in the secondary and tertiary sectors.

Moreover, we have to note that, unlike China, over the whole period (i.e. before and after the reforms) the absolute and relative employment in services was always higher than in the secondary sector. In Table 8 , we also show the employment indexes for two sub-periods: 1980-92, before the trade policy reforms, and 1992-04, after these reforms. As we can see, employment increased over both periods, but its growth was

\footnotetext{
12 The National Bureau of Statistics of China does not provide reliable data disaggregated by branch of industry. Szirmai et al. revised official statistics and estimated the added value and the employment by branch of industry (Szirmai et al., 2005). Although these estimations are not representative for all the firms (just medium and large firms were considered) and employees (data are available just for staff and workers), they anyway are a useful source to delineate the productivity growth within industry.
} 
faster before the reforms. Looking at subsector level (Figure 5), it is clear that, apart from agriculture, most workers were employed in manufacturing, wholesale, retail trade, hotels, restaurant and community, social and personal services. However, the highest employment growth rates concerned construction, real estate, insurance and financial intermediation.

Table 8. Employed persons by industry and share in India, 1980=100

\begin{tabular}{|l|l|l|l|l|l|l|l|}
\hline & $\begin{array}{l}\text { Total } \\
\text { employed } \\
\text { persons }\end{array}$ & Primary & share & Secondary & share & Tertiary & share \\
\hline 1980 & 100.0 & 100.0 & 0.72 & 100.0 & 0.11 & 100.0 & 0.17 \\
1985 & 112.5 & 108.8 & 0.70 & 120.4 & 0.12 & 123.3 & 0.18 \\
1990 & 128.0 & 118.3 & 0.67 & 147.0 & 0.13 & 158.0 & 0.21 \\
1995 & 144.3 & 128.3 & 0.64 & 192.4 & 0.15 & 182.0 & 0.21 \\
2000 & 162.8 & 139.2 & 0.62 & 251.8 & 0.17 & 206.8 & 0.21 \\
2004 & 161.6 & 139.0 & 0.62 & 231.0 & 0.16 & 214.4 & 0.22 \\
$1980-92$ & 133.4 & 122.3 & & 158.8 & & 164.9 & \\
$(1980=100)$ & & & & 145.5 & & 130.0 & \\
$1992-04$ & 121.2 & 113.7 & & & & & \\
$(1992=100)$ & \multicolumn{7}{|c|}{ Source: our calculations based on GGDC data. }
\end{tabular}

Table 9. Employed persons $(E)$ and productivity $(P)$ by sector in India, 1980=100

\begin{tabular}{|c|c|c|c|c|c|c|c|c|c|c|}
\hline & \multicolumn{2}{|c|}{$\begin{array}{l}\text { Agriculture, } \\
\text { Forestry, and } \\
\text { Fishing }\end{array}$} & \multicolumn{2}{|c|}{$\begin{array}{l}\text { Mining and } \\
\text { Quarrying }\end{array}$} & \multicolumn{2}{|c|}{$\begin{array}{l}\text { Manufactu- } \\
\text { ring }\end{array}$} & \multicolumn{2}{|c|}{$\begin{array}{l}\text { Public } \\
\text { Utilities }\end{array}$} & \multicolumn{2}{|c|}{ Construction } \\
\hline & $\mathbf{E}$ & $\mathbf{P}$ & $\mathbf{E}$ & $\mathbf{P}$ & $\mathbf{E}$ & $\mathbf{P}$ & $\mathbf{E}$ & $\mathbf{P}$ & $\mathbf{E}$ & $\mathbf{P}$ \\
\hline 1980 & 100 & 100 & 100 & 100 & 100 & 100 & 100 & 100 & 100 & 100 \\
\hline 1985 & 109 & 107 & 130 & 106 & 119 & 118 & 111 & 133 & 132 & 89 \\
\hline 1990 & 118 & 119 & 197 & 112 & 138 & 150 & 129 & 177 & 202 & 80 \\
\hline 1995 & 128 & 122 & 227 & 123 & 177 & 163 & 173 & 195 & 306 & 63 \\
\hline 2000 & 139 & 128 & 231 & 145 & 227 & 162 & 216 & 209 & 461 & 58 \\
\hline \multirow[t]{3}{*}{2004} & 139 & 140 & 258 & 163 & 205 & 229 & 212 & 246 & 430 & 83 \\
\hline & \multicolumn{2}{|c|}{$\begin{array}{l}\text { Wholesale } \\
\text { and Retail } \\
\text { Trade, } \\
\text { Hotels and } \\
\text { Restaurants }\end{array}$} & \multicolumn{2}{|c|}{$\begin{array}{l}\text { Transport, } \\
\text { Storage, and } \\
\text { Communica- } \\
\text { tion }\end{array}$} & \multicolumn{2}{|c|}{$\begin{array}{l}\text { Finance, } \\
\text { Insurance, } \\
\text { and Real } \\
\text { Estate }\end{array}$} & \multicolumn{2}{|c|}{$\begin{array}{l}\text { Community, } \\
\text { Social, } \\
\text { Personal and } \\
\text { Government } \\
\text { Services }\end{array}$} & \multicolumn{2}{|c|}{ ECONOMY } \\
\hline & $\mathbf{E}$ & $\mathbf{P}$ & $\mathbf{E}$ & $\mathbf{P}$ & $\mathbf{E}$ & $\mathbf{P}$ & $\mathbf{E}$ & $\mathbf{P}$ & $\mathbf{E}$ & $\mathbf{P}$ \\
\hline 1980 & 100 & 100 & 100 & 100 & 100 & 100 & 100 & 100 & 100 & 100 \\
\hline 1985 & 136 & 98 & 120 & 116 & 116 & 157 & 117 & 113 & 112 & 114 \\
\hline 1990 & 186 & 97 & 145 & 135 & 147 & 227 & 145 & 127 & 128 & 136 \\
\hline 1995 & 217 & 110 & 179 & 138 & 311 & 183 & 157 & 151 & 144 & 153 \\
\hline 2000 & 249 & 133 & 219 & 177 & 615 & 136 & 161 & 227 & 163 & 180 \\
\hline 2004 & 274 & 171 & 210 & 294 & 796 & 138 & 155 & 298 & 162 & 232 \\
\hline
\end{tabular}


In sum, it seems that in India the reallocation of workers was less clear, but anyway important: while in 2004 employment in the primary sector was still predominant, there was a movement of workers toward manufacturing on the one hand, and traditional services on the other hand; at the same time also modern services were witnessing a significant employment growth. Before the reforms, productivity was already increasing in all sectors (Figure 6).

Figure 5. Number of employed persons by sector and subsector in India (thousands)

By sector

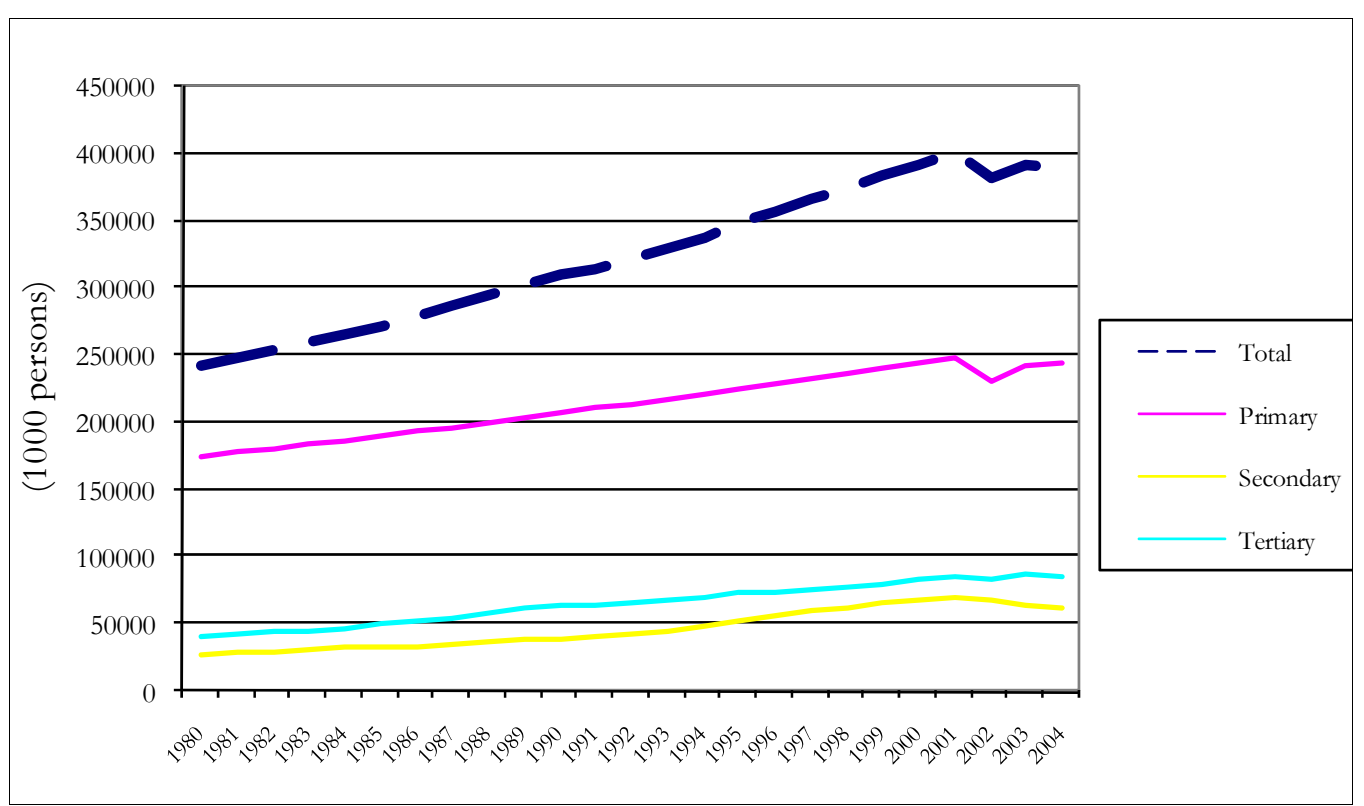

By subsector

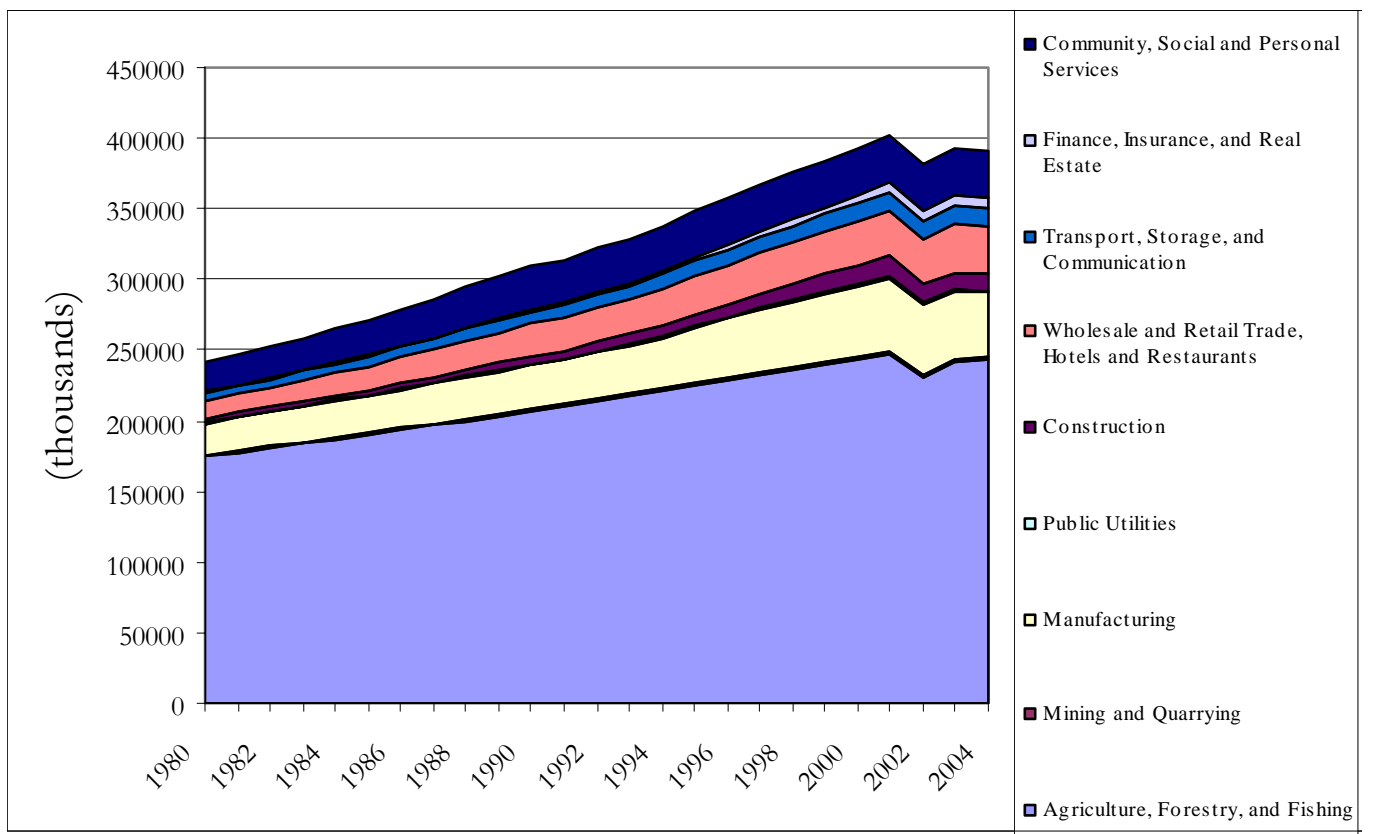

Source: GGDC. 
However, after the economic reforms this increase accelerated, above all in the tertiary sector. Starting from 1996, services became the sector with the highest productivity level. Observing the picture in detail, we can see that the productivity growth was lower but better distributed among sectors with respect to the Chinese case. The subsectors gaining in terms of productivity growth were not only manufacturing, but also public utilities, transport, storage and communication, with community, social, personal and government services as leader sectors. Unlike in the Chinese case, in these sectors also employment grew but at a lower rate than output. On the contrary, finance, insurance and real estate showed unbalanced development. Before the reforms, these services had a growth in employment (84\% in 1980-1992) lower than the productivity growth $(122 \%)$.

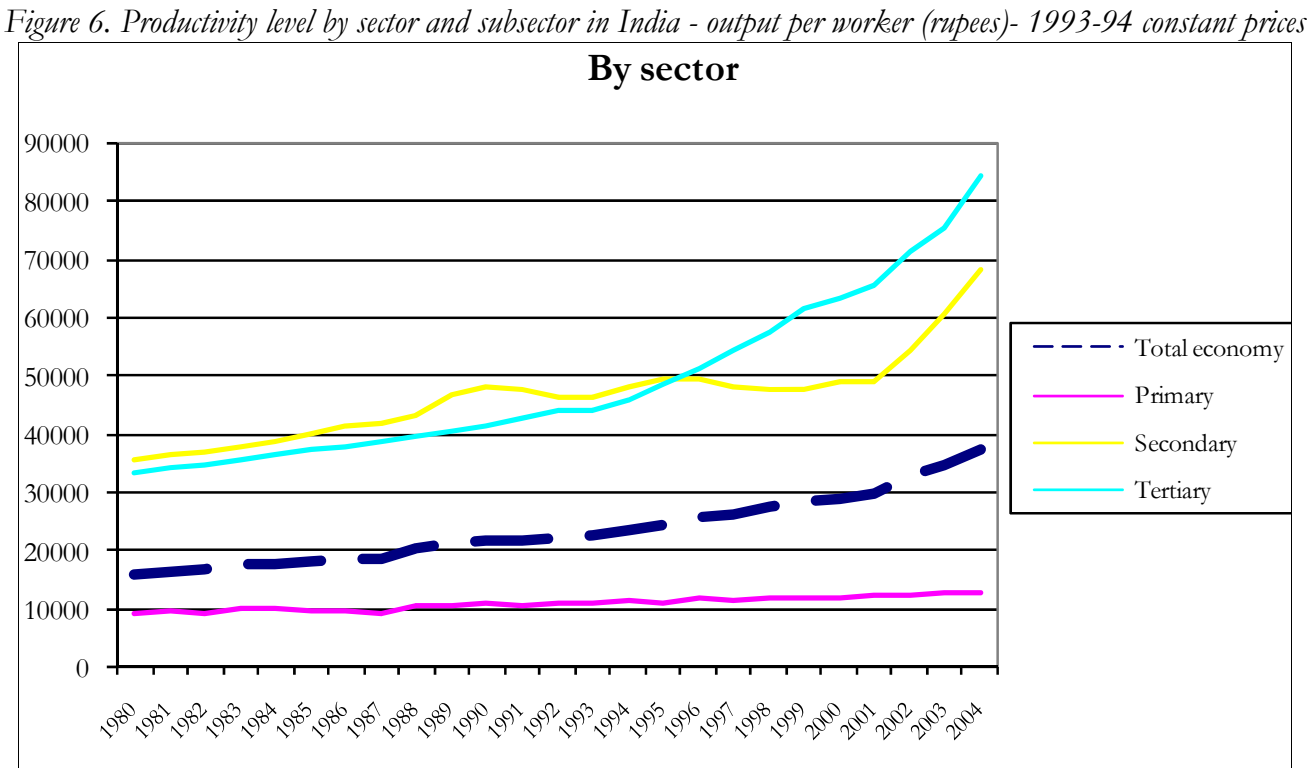

\section{By subsector}



Source: our calculations based on GGDC data. Sectors are encoded in the following way: 1_ Agriculture, Forestry, and Fishing; 1_Mining and Quarrying; 3_Manufacturing; 4_Public Utilities; 5_Construction; 6_Wholesale and Retail Trade, Hotels and Restaurants; 7 Transport, Storage, and Communication; $\overline{8}_{-}$Finance, Insurance, and Real Estate; 9 Community, Social, Personal and Government Services. 
However, after the reforms this trend reversed: in 2004 these subsectors presented the highest employment growth (696\% with respect to 1980$)$ but a decreasing labour productivity (Table 9).

The more balanced pattern of growth with respect to the Chinese one is demonstrated by decomposing labour productivity growth. The contributions by each sector and subsector, indeed, are less divergent, although some sectors led the process more than others: manufacturing and overall services. Even if the highest contribution was given by the increase in productivity within-sectors $(68 \%$ in the period after the reforms), it was accompanied by a balanced reallocation of workers towards sectors with high productivity ( $32 \%$ in the same period).

Table 10. Decomposition of labour productivity growth in India - percentage contribution by 9 sectors

\begin{tabular}{|l|l|l|l|}
\hline & $\mathbf{1 9 8 0 - 9 2}$ & $\mathbf{1 9 9 2 - 0 4}$ & $\mathbf{1 9 8 0 - 0 4}$ \\
\hline PRODUCTIVITY EFFECT & 64.8 & 68.2 & 75.8 \\
REALLOCATION EFFECT & 35.2 & 31.8 & 24.2 \\
TOTAL EFFECT & 100 & 100 & 100 \\
\multicolumn{1}{|c|}{ Calculations based on 1993-94 constant prices. Source: our calculations based on GGDC data. }
\end{tabular}

It must be underlined that this analysis is based on reallocation flows by industry but it doesn't consider the institutional framework regarding the labour market. Indeed, when also the distinction between formal and informal sectors is taken into account, the contribution of labour reallocation in terms of productivity growth is reduced. The movement of workers from agriculture to other sectors increased labour productivity; however, this effect was partially counterbalanced by the movement of workers from formal to informal sectors, where not only productivity but also wages are very low and illiteracy is substantial (OECD, 2007; Dougherty at al., 2009).

\section{Conclusions}

As mentioned in the introduction, the rise in industrial activities was anticipated in time, becoming more intense and wider in scope in China than in India, where industry is nevertheless gaining momentum. The fordist model of growth operated in China earlier and much more intensively than in India. There are very important differences in the pattern of growth of the two countries, some of which closely associated to the different timing and amplitude of structural changes.

Not only has China a much larger industrial sector than India, even discounting the fact that its rapid industrialization process began some 12-15 years earlier than in India, but also its industrial activities are much less fragmented. India has an extraordinarily large number of micro-enterprises and a very vast "informal economy", much larger than China's. Moreover, India has a very large chain of production intermediaries and of wholesale and retail traders. These long production and distributive chains may sustain employment and reduce labour costs, but decrease productivity and tend to greatly increase the spread between prices earned by producers and consumer prices.

In India the software sector is more advanced than in China, although an important part of the sector is carried out as sub-contractor of foreign companies, while the production of hardware in India is much weaker than in China. China has 
experienced a much larger structural transformation than India, partly due to a deeper integration in the world economy.

Some of the differences in the productive structure are associated with the differences in education in the two countries. India has a more bi-polar system. It has, in fact, a large mass of people illiterate or with a weak command of the more diffused national languages and no knowledge of foreign languages as English, and at the same time, a consistent and rapidly growing number of engineers, microelectronics experts and other University graduates with a good knowledge of English. China has a less differentiated education system, with, on the average, a more educated work-force, but with increasing inequalities in the access to higher education and high quality schools. ${ }^{13}$

Owing to its earlier economic period of rapid growth and to its more centralized decision-making process, China has created, in its more economically dynamic zones, better transport and communication infrastructure than India. Lower transport and trading costs and larger scale economies in some sectors have contributed to increase the international competitiveness of China if compared with India.

While the Indian banking and financial market appears to be more advanced and sophisticated than the Chinese market, the latter has grown more rapidly and has greatly benefited from the return under the control of China of the great and sophisticated financial market of Hong Kong. ${ }^{14}$

Finally, since 1978, pollution and income and wealth inequalities among families and among regions have increased both in China and in India, but much more markedly in China. Although the extent of poverty has diminished in both countries, it remains very large in India and sizeable in various parts of China.

\section{References}

Amighini A. (2005), 'China in the International Fragmentation of Production: Evidence from the ICT Industry', European Journal of Comparative Economics", 2

Balcet G. Bruschieri S. (2008), 'Technology transfer, Joint Ventures and the Emergence of Indian Multinationals: the Case of the Automotive Industry', Asia and Europe: Connections and Contrasts, Anderosso-O'Callaghan B., Zolin M.B. (eds), Libreria Editrice Cafoscarina, Venezia

Basu K. (2007) (ed.) The Oxford Companion to economics in India, Oxford, Oxford University Press.

Bossworth B., Collins S.M. (2008), 'Accounting for Growth: Comparing China and India', The Journal of Economic Perspectives, 22(1), 45-65.

Chenery H.B. et al. (1979), Structural change and development policy, New York Oxford University Press

\footnotetext{
${ }^{13}$ See, for the Chinese case, Saccone (2008).

${ }^{14}$ For an analysis of the Chinese financial market see, for example, Sau (2008) and (2009), Chiarlone, Ferri (2007).
} 
Chenery H.B., Robinson S., Syrquin M. (1986), Industrialization and growth: a comparative study, New York, Oxford University Press

Chiarlone S. , Ferri G. (2007), 'Problemi e prospettive del sistema bancario cinese', I sistemi bancari dei paesi emergenti, Chiarlone S., Ferri G., pp. 61-98, Bancaria editrice, Roma

Chiarlone S., Amighini A. (2007), L'economia della Cina, Carocci, Roma

Dougherty S., Herd R., Chalaux T. (2009), 'What is Holding Back Productivity Growth in India? Recent Microevidence', OECD Journal: Economic Studies, 2009

Frankel F.R. (2005), Indian's Political economy: 1947-2004, Oxford, Oxford University Press

Fuà G. (1980), Problemi dello sviluppo tardivo in Europa, Il Mulino, Bologna

Galbraith J.K., Krytynskaia L. (2004), Wang Q., 'The Experience of Rising Inequality in Russia and China during the Transition', European Journal of Comparative Economics, 1

Gerschenkron A. (1962), Economic Backwardness in Historical Perspective, Harvard University Press, Cambridge, Mass

GGDC (2009), Total Data Base, Groningen Growth and Development Center, available at: http://www.eco.rug.nl/ggdc

Herd S., Dougherty R. (2007), 'Growth Prospects in China and India Compared', European Journal of Comparative Economics, June 2007

IMF (2006), 'Asia rising: patterns of economic development and growth', World Economic Outlook, Washington D.C.

Kuznets S. (1966), Modern Economic Growth: Rate, Structure, and Spread, Yale University Press, New Haven, London

Maddison A. (2007), Contours of the World Economy. 1-2030 AD, Oxford University Press, Oxford Maddison A. (2007), Chinese Economic Performance in the Long Run, 2nd edition, OECD, Paris

Maddison A., Wu H.X. (2008), 'Measuring China’s Economic Performance', World Economics, 9(2), April-June

Malle S. (2006), 'Profili macro-economici della Cina', Il Politico, Settembre-Dicembre, 194-216

National Bureau of Statistics of China (2008), China Statistics Yearbook

National Bureau of Statistics of China (2009), http://www.stats.gov. cn/english/

OECD (2005), OECD Economic Surveys: China, Paris.

OECD (2007) OECD Economic Surveys: India, Paris.

Pasinetti L. (1981), Structural Change and Economic Growth, Cambridge University Press, Cambridge 
Richet X, Ruet J. (2008), The Chinese and Indian Automobile Industry in Perspective: Technology Appropriation, Catching-up and Development, forthcoming

Saccone D. (2008) 'Educational Inequality and Educational Poverty: the Chinese Case in the Period 1975-2004', Working papers, 8, Department of Economics, University of Turin

Sau L. (2008), 'La struttura del sistema finanziario in Cina', Working papers, 7, Department of Economics, University of Turin

Sau L. (2009), 'Gradualism and the Evolution of the Financial Structure in China', Working papers, 3, Department of Economics, University of Turin

Syrquin M. (1986), 'Productivity growth and factor reallocation', Industrialization and growth, in H.

B. Chenery (Ed.), Oxford University Press, Oxford

Szirmai A., Ren R., Bai M. (2005), 'Chinese Manufacturing Performance in Comparative Perspective, 1980-2002', Center Discussion Paper, 920, Economic Growth Center, Yale University.

UNDP (2008), Human Development Report, Oxford University Press, Oxford

Valli V. (2002), L'Europa e l'economia mondiale, Carocci, Roma

Valli V. (2005), Politica economica. Introduzione all'economia dello sviluppo, Carocci, Roma

Valli V. (2009). 'The Three Waves of the Fordist Model of Growth and the Case of China', Working papers, 5, Department of Economics, University of Turin

World Bank (2009), World Development Indicators, Washington D.C. 


\section{Statistical Appendix}

Table A1. Decomposition of labour productivity growth in China- percentage contribution by 7 subsectors

\begin{tabular}{|l|l|l|l|}
\hline & $\mathbf{1 9 8 0 - 9 2}$ & $\mathbf{1 9 9 2 - 0 2}$ & $\mathbf{1 9 8 0 - 0 2}$ \\
\hline Agriculture, forestry, animal husbandry and fishery & & & \\
\hline productivity effect & 16.0 & 7.8 & 8.7 \\
\hline reallocation effect & -4.5 & 1.4 & -0.7 \\
\hline TOTAL EFFECT & $\mathbf{1 1 . 5}$ & $\mathbf{9 . 2}$ & $\mathbf{8 . 1}$ \\
\hline Industry (manufacturing, mining and utilities) & & & \\
\hline productivity effect & 59.1 & 90.4 & 71.9 \\
\hline reallocation effect & 10.7 & -3.0 & 1.8 \\
\hline TOTAL EFFECT & $\mathbf{6 9 . 8}$ & $\mathbf{8 7 . 4}$ & $\mathbf{7 3 . 7}$ \\
\hline Construction & & & \\
\hline productivity effect & 1.2 & 3.0 & 2.4 \\
\hline reallocation effect & 2.5 & 0.3 & 1.1 \\
\hline TOTAL EFFECT & $\mathbf{3 . 7}$ & $\mathbf{3 . 3}$ & $\mathbf{3 . 5}$ \\
\hline Wholesale, retail trade, hotels and catering services & & & \\
\hline productivity effect & 1.7 & -4.2 & -1.4 \\
\hline reallocation effect & 1.6 & -4.1 & 1.6 \\
\hline TOTAL EFFECT & $\mathbf{3 . 3}$ & $\mathbf{- 8 . 3}$ & $\mathbf{0 . 2}$ \\
\hline Financial intermediation & & & \\
\hline productivity effect & 5.7 & -1.0 & 2.6 \\
\hline reallocation effect & 1.8 & 3.8 & 1.3 \\
\hline TOTAL EFFECT & $\mathbf{7 . 5}$ & $\mathbf{2 . 8}$ & $\mathbf{3 . 9}$ \\
\hline Real estate & & & \\
\hline productivity effect & 3.1 & -0.5 & 1.5 \\
\hline reallocation effect & 3.2 & 3.3 & 2.3 \\
\hline TOTAL EFFECT & $\mathbf{6 . 4}$ & $\mathbf{2 . 8}$ & $\mathbf{3 . 8}$ \\
\hline Other services & & & \\
\hline productivity effect & 0.4 & 12.4 & 8.3 \\
\hline reallocation effect & -2.5 & -9.5 & -1.4 \\
\hline TOTAL EFFECT & $\mathbf{- 2 . 1}$ & $\mathbf{2 . 9}$ & $\mathbf{6 . 9}$ \\
\hline $\begin{array}{l}\text { TOTAL ECONOMY } \\
\text { reallocation effect }\end{array}$ & & & \\
\hline COTAL EFFECT & $\mathbf{1 0 0}$ & $\mathbf{1 0 0}$ & $\mathbf{1 0 0}$ \\
\hline
\end{tabular}

Calculations are based on 1980 constant prices.

Source: our calculations based on China Statistical Yearbook data (various years). 
Table A2. Decomposition of labour productivity growth in Chinese industry- percentage contribution by branch

\begin{tabular}{|c|c|c|c|}
\hline & 1980-92 & 1992-02 & 1980-02 \\
\hline \multicolumn{4}{|l|}{ Food manufacturing } \\
\hline productivity effect & 5.1 & 5.6 & 5.5 \\
\hline reallocation effect & -0.2 & 0.0 & 0.0 \\
\hline TOTAL EFFECT & 4.9 & 5.6 & 5.5 \\
\hline \multicolumn{4}{|c|}{ Beverage manufacturing } \\
\hline productivity effect & 2.7 & 2.0 & 2.2 \\
\hline reallocation effect & 0.7 & -0.1 & 0.1 \\
\hline TOTAL EFFECT & 3.5 & 2.0 & 2.2 \\
\hline \multicolumn{4}{|l|}{ Tobacco processing } \\
\hline productivity effect & 4.4 & 4.0 & 4.1 \\
\hline reallocation effect & 5.8 & -0.5 & 0.5 \\
\hline TOTAL EFFECT & 10.2 & 3.5 & 4.6 \\
\hline \multicolumn{4}{|l|}{ Textile industry } \\
\hline productivity effect & -5.5 & 6.8 & 5.6 \\
\hline reallocation effect & 3.4 & 0.8 & 0.0 \\
\hline TOTAL EFFECT & -2.0 & 7.5 & 5.6 \\
\hline \multicolumn{4}{|l|}{ Clothing industry } \\
\hline productivity effect & 2.9 & 2.3 & 2.5 \\
\hline reallocation effect & -1.3 & 0.0 & -0.2 \\
\hline TOTAL EFFECT & 1.6 & 2.3 & 2.3 \\
\hline \multicolumn{4}{|c|}{ Leather and fur products } \\
\hline productivity effect & 0.3 & 1.3 & 1.2 \\
\hline reallocation effect & -0.5 & 0.0 & -0.1 \\
\hline TOTAL EFFECT & -0.3 & 1.3 & 1.1 \\
\hline \multicolumn{4}{|l|}{ Wood products } \\
\hline productivity effect & -0.4 & 0.6 & 0.5 \\
\hline reallocation effect & -0.4 & 0.1 & 0.0 \\
\hline TOTAL EFFECT & -0.8 & 0.8 & 0.5 \\
\hline \multicolumn{4}{|c|}{ Paper and printing products } \\
\hline productivity effect & 1.2 & 2.5 & 2.3 \\
\hline reallocation effect & -0.6 & 0.2 & 0.0 \\
\hline TOTAL EFFECT & 0.6 & 2.7 & 2.3 \\
\hline \multicolumn{4}{|c|}{ Oil refining, coking and coal products } \\
\hline productivity effect & -6.1 & -0.1 & -0.8 \\
\hline reallocation effect & 7.8 & -0.2 & 0.7 \\
\hline TOTAL EFFECT & 1.7 & -0.3 & 0.0 \\
\hline \multicolumn{4}{|c|}{ Chemical industry, excl. oil } \\
\hline productivity effect & 14.6 & 11.9 & 12.2 \\
\hline reallocation effect & 2.0 & -0.5 & 0.1 \\
\hline TOTAL EFFECT & 16.6 & 11.4 & 12.4 \\
\hline \multicolumn{4}{|l|}{ Rubber and plastics } \\
\hline productivity effect & 1.6 & 2.9 & 2.7 \\
\hline reallocation effect & 0.5 & 0.0 & 0.0 \\
\hline TOTAL EFFECT & 2.1 & 2.9 & 2.8 \\
\hline \multicolumn{4}{|c|}{ Non-metallic minerals } \\
\hline productivity effect & 6.0 & 2.9 & 3.2 \\
\hline reallocation effect & -3.1 & 0.6 & -0.1 \\
\hline TOTAL EFFECT & 2.9 & 3.5 & 3.1 \\
\hline
\end{tabular}




\begin{tabular}{|c|c|c|c|}
\hline \multicolumn{4}{|l|}{ Basic metals } \\
\hline productivity effect & 4.5 & 5.0 & 5.0 \\
\hline reallocation effect & 1.4 & -0.1 & 0.1 \\
\hline TOTAL EFFECT & 5.8 & 4.9 & 5.1 \\
\hline \multicolumn{4}{|l|}{ Fabricated metals } \\
\hline productivity effect & 0.7 & 2.1 & 2.0 \\
\hline reallocation effect & -0.8 & 0.4 & 0.1 \\
\hline TOTAL EFFECT & 0.0 & 2.5 & 2.0 \\
\hline \multicolumn{4}{|l|}{ Machinery } \\
\hline productivity effect & 15.3 & 9.5 & 9.6 \\
\hline reallocation effect & -2.1 & 0.6 & 0.4 \\
\hline TOTAL EFFECT & 13.2 & 10.0 & 10.0 \\
\hline \multicolumn{4}{|c|}{ Transport equipment } \\
\hline productivity effect & 10.9 & 11.2 & 11.5 \\
\hline reallocation effect & -0.9 & 0.0 & -0.1 \\
\hline TOTAL EFFECT & 10.0 & 11.2 & 11.4 \\
\hline \multicolumn{4}{|c|}{ Electrical machinery and equipment } \\
\hline productivity effect & 4.4 & 5.2 & 5.2 \\
\hline reallocation effect & -0.5 & 0.0 & 0.0 \\
\hline TOTAL EFFECT & 3.9 & 5.3 & 5.1 \\
\hline \multicolumn{4}{|c|}{ Electronic and telecom equipment } \\
\hline productivity effect & 4.7 & 9.0 & 8.9 \\
\hline reallocation effect & -0.6 & 0.0 & -0.1 \\
\hline TOTAL EFFECT & 4.1 & 9.0 & 8.7 \\
\hline \multicolumn{4}{|l|}{ Instruments } \\
\hline productivity effect & 0.7 & 0.8 & 0.8 \\
\hline reallocation effect & -0.1 & 0.0 & 0.0 \\
\hline TOTAL EFFECT & 0.6 & 0.8 & 0.8 \\
\hline \multicolumn{4}{|l|}{ Furniture } \\
\hline productivity effect & 0.1 & 0.4 & 0.4 \\
\hline reallocation effect & 0.0 & 0.1 & 0.1 \\
\hline TOTAL EFFECT & 0.1 & 0.5 & 0.4 \\
\hline \multicolumn{4}{|c|}{ Other manufacturing } \\
\hline productivity effect & 1.8 & 2.1 & 2.1 \\
\hline reallocation effect & -0.9 & 0.1 & -0.1 \\
\hline TOTAL EFFECT & 0.9 & 2.2 & 2.0 \\
\hline \multicolumn{4}{|l|}{ Mining and Utilities } \\
\hline productivity effect & 17.4 & 10.3 & 11.5 \\
\hline reallocation effect & 3.1 & -0.1 & 0.4 \\
\hline TOTAL EFFECT & 20.6 & 10.1 & 11.9 \\
\hline \multicolumn{4}{|c|}{ TOTAL INDUSTRY } \\
\hline productivity effect & 87.3 & 98.6 & 98.3 \\
\hline reallocation effect & 12.7 & 1.4 & 1.7 \\
\hline TOTAL EFFECT & 100 & 100 & 100 \\
\hline
\end{tabular}

Calculations are based on 1980 constant prices. Source: our calculations based on Szirmai et al. (2005). 
Table A3. Decomposition of labour productivity growth in India - percentage contribution by 9 subsectors

\begin{tabular}{|c|c|c|c|}
\hline & $1980-92$ & $1992-04$ & 1980-04 \\
\hline \multicolumn{4}{|c|}{ Agriculture, Forestry, and Fishing } \\
\hline productivity effect & 18.6 & 8.0 & 10.8 \\
\hline reallocation effect & -13.3 & -5.7 & -5.7 \\
\hline TOTAL EFFECT & 5.3 & 2.3 & 5.1 \\
\hline \multicolumn{4}{|c|}{ Mining and Quarrying } \\
\hline productivity effect & 1.1 & 1.9 & 1.6 \\
\hline reallocation effect & 3.6 & 0.6 & 1.3 \\
\hline TOTAL EFFECT & 4.7 & 2.5 & 2.9 \\
\hline \multicolumn{4}{|l|}{ Manufacturing } \\
\hline productivity effect & 16.8 & 17.2 & 17.8 \\
\hline reallocation effect & 4.9 & 2.9 & 2.6 \\
\hline TOTAL EFFECT & 21.7 & 20.2 & 20.4 \\
\hline \multicolumn{4}{|l|}{ Public Utilities } \\
\hline productivity effect & 4.2 & 1.3 & 2.4 \\
\hline reallocation effect & 1.1 & 1.3 & 0.7 \\
\hline TOTAL EFFECT & 5.3 & 2.6 & 3.2 \\
\hline \multicolumn{4}{|l|}{ Construction } \\
\hline productivity effect & -7.4 & 1.8 & -2.0 \\
\hline reallocation effect & 12.6 & 3.6 & 7.5 \\
\hline TOTAL EFFECT & 5.2 & 5.4 & 5.5 \\
\hline \multicolumn{4}{|c|}{$\begin{array}{l}\text { Wholesale and Retail Trade, Hotels } \\
\text { and Restaurants }\end{array}$} \\
\hline productivity effect & 0.1 & 17.5 & 12.4 \\
\hline reallocation effect & 15.4 & 3.5 & 6.9 \\
\hline TOTAL EFFECT & 15.5 & 21.0 & 19.3 \\
\hline \multicolumn{4}{|c|}{$\begin{array}{l}\text { Transport, Storage, and } \\
\text { Communication }\end{array}$} \\
\hline productivity effect & 7.7 & 14.1 & 12.4 \\
\hline reallocation effect & 4.4 & 2.0 & 2.1 \\
\hline TOTAL EFFECT & 12.1 & 16.1 & 14.5 \\
\hline \multicolumn{4}{|c|}{ Finance, Insurance, and Real Estate } \\
\hline productivity effect & 12.3 & -12.7 & 4.0 \\
\hline reallocation effect & 4.0 & 23.4 & 8.0 \\
\hline TOTAL EFFECT & 16.3 & 10.7 & 12.0 \\
\hline \multicolumn{4}{|c|}{$\begin{array}{l}\text { Community, Social, Personal and } \\
\text { Government Services }\end{array}$} \\
\hline productivity effect & 11.4 & 19.0 & 16.3 \\
\hline reallocation effect & 2.5 & 0.1 & 0.7 \\
\hline TOTAL EFFECT & 13.9 & 19.1 & 17.0 \\
\hline \multicolumn{4}{|c|}{ TOTAL ECONOMY } \\
\hline productivity effect & 64.8 & 68.2 & 75.8 \\
\hline reallocation effect & 35.2 & 31.8 & 24.2 \\
\hline TOTAL EFFECT & 100 & 100 & 100 \\
\hline
\end{tabular}

Calculations are based on 1993-94 constant prices. Source: our calculations based on GGDC data. 